\title{
http://jaet.journals.ekb.eg \\ NUTRIENTS REMOVAL FROM PARTIALLY TREATED WASTEWATER USING SOIL AQUIFER TREATMENT SYSTEM
}

\author{
Haitham M. Amin ${ }^{1 *}$, Ali A.M. Gad ${ }^{2}$, Usama A. Abdelghany ${ }^{3}$, Rabiee A. Sadeek ${ }^{4}$ \\ ${ }^{1}$ Assistant Lecturer, Civil Engineering Department, Faculty of Eng., Al-Azhar University, Qena, Egypt \\ ${ }^{2}$ Professor, Civil Engineering Department, Faculty of Eng., Assiut University, Egypt \\ ${ }^{3}$ Associate professor, Civil Engineering Department, Faculty of Eng., Al-Azhar University, Qena, Egypt \\ ${ }^{4}$ Professor, Civil Engineering Department, Faculty of Eng., Minia University, Egypt \\ *Corresponding Author E-mail: HaithamAmin.e20@azhar.edu.eg
}

\begin{abstract}
This study aims to evaluate SAT system in removing nutrients and bacteriological pollution (heterotrophic bacteria) from partially wastewater, and reuse the treated wastewater in agriculture according to Egyptian Code of Practice (ECP) and Food and Agriculture Organization (FAO) limits. Results indicated that the SAT system is effective in removing nutrients and heterotrophic bacteria from wastewater. The vadose zone acts as a filter and it is effective in removing contaminants from wastewater. The suitable distance for extracting water with acceptable quality is $750 \mathrm{~m}$ from the infiltration basin. Organic nitrogen, ammonia, nitrite, phosphate, and total Kjeldahl nitrogen were effectively removed with an efficiency of $100 \%$. Heterotrophic bacteria's concentration decreased with a removal efficiency of nearly $99.9 \%$ at $1500 \mathrm{~m}$. According to FAO and ECP, limits the reclaimed water is suitable for irrigation.
\end{abstract}

Keywords: Soil aquifer treatment, Wastewater Treatment, Wastewater reuse, Nutrients, Heterotrophic bacteria

\section{INTRODUCTION}

Soil aquifer treatment (SAT) systems are unconventional water resources; they are used to recharge partially treated wastewater through the unsaturated layer (vadose zone) to the aquifer. This technique achieves additional improvements in wastewater quality using various biochemical or physical soil processes $[1,2]$. The vadose zone acts as a filter for the groundwater by removing contaminants that might come from the land surface [3].

The SAT is becoming a common practice in arid and semi-arid regions to produce water with acceptable quality $[4,5]$. It has been carried out in many countries around the world [6-9].

Recharged wastewater percolates through the vadose zone and a series of chemical, physical, and biological treatment processes occurs $[10,11]$ until it reaches the groundwater. SAT systems efficiently remove contaminants from the recharged water such as suspended solids, heavy metals, microorganisms, and ammonium. They reduce biological and chemical oxygen demand. Furthermore, they minimize the use of chemicals and energy [12].

Based on the fact that biological degradation was active within the upper $30 \mathrm{~cm}$ of the soil layer $[13,14]$, the natural dilution processes occur in the soil and sub-soil, particularly in the unsaturated zone. The availability of oxygen in the vadose zone, especially at the top layer $(<1.5 \mathrm{~m})$ that is controlled by alternate flooding/drying periods [ 11 , Revised:21 Septamber, 2021, Accepted:19April , 2021
15-17] is the main factor influencing the transformations of nitrogen and carbon in the process. Nitrification and denitrification occur mostly in the upper layers of the soil, where organic carbon is sufficient and degradable [18].

The most important advantages of SAT are mitigating depletion of groundwater levels [19, 20], protecting coastal aquifers from saltwater intrusion [8], storing surface water for future use, its cost is considered less than that of conventional treatment methods, improving recharged and groundwater quality, has low operation and maintenance, and is an economically feasible tertiary treatment for reuse in arid and semi-arid regions [10, 11, 21-25].

The bane of all SAT systems is the clogging of the infiltrating surface and that results in a reduction in infiltration rates [26, 27]. Limiting the total suspended solid concentration in the recharged water. Moreover, restricting the water depth to $30 \mathrm{~cm}$, together with periodic scraping or disking of basins has been effective in reducing the rate of clogging to a manageable level [28].

The partially treated wastewater that contains high levels of nutrients, may lead to eutrophication of the receiving water bodies. When it's reused in irrigation, it can reduce some crop yields, even though there may be a more luxuriant growth of the non-useful parts of the crop [29]. The main aim of the present study is to investigate the effect of the SAT system in removing nutrients and heterotrophic bacteria from partially treated wastewater to be reused in unrestricted irrigation. 
Furthermore, participation in solving agricultural water shortage problems in Egypt, especially in the desert regions.

\section{MATERIALS AND METHODS}

\subsection{Study area}

The study area is situated in the west of the Nile River at Sohag governorate (El-Dair region). It is occupied by a thick succession of sandy and gravely Pleistocene sediments. It is covered with a thin layer of recent wadi deposits (sandy gravel) ranging in thickness from $1 \mathrm{~m}$ to more than $10 \mathrm{~m}$ [30]. This site is bounded by the cultivated floodplain from the east and the Eocene limestone plateau from the west [31]. The depth of the water table in the study area is nearly 25-30 m [32] and the flow direction is in the northeast direction [33]. The infiltration basin is located in El-Dair region west of Sohag city (Figure 1). Currently, the infiltration basin's water comes from the west of the Sohag wastewater treatment plant.

\subsection{Wastewater treatment plant}

The treatment plant is located $12 \mathrm{~km}$ west of Sohag city (Figure 1). It was established in 1995 (the oldest wastewater treatment plant in Sohag Governorate) with a design capacity of more than $40,000 \mathrm{~m}^{3} /$ day. It serves people living in the western part of the Nile Valley in the city.

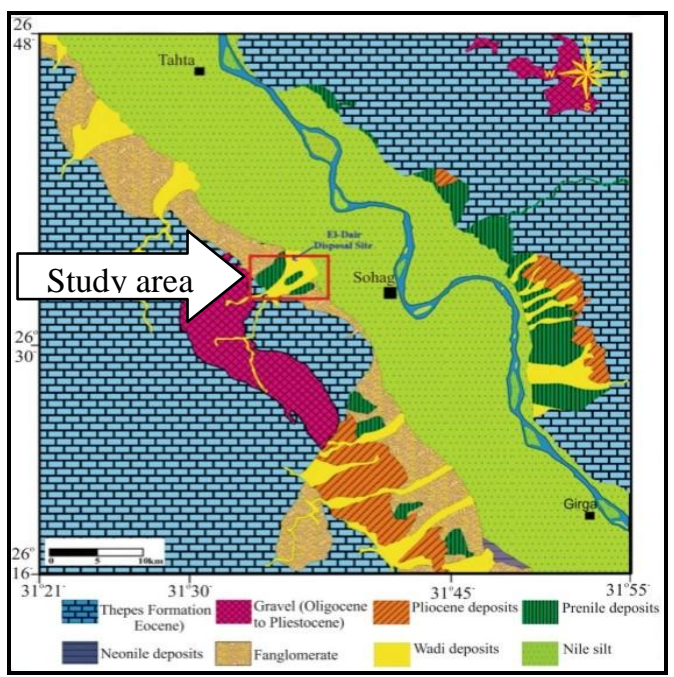

Fig. 1. Location of El-Dair region [34].

In the west of the Sohag treatment plant, wastewater is treated by primary treatment followed by an aerobic activated-sludge process and clarifiers. Then the secondary effluent is allowed to irrigate wooden forests, which infiltrate the soil through flooding basins into the aquifer.

\subsection{Infiltration basin}

The infiltration basin is located in the area bounded by the cultivated land from the east and the Eocene limestone plateau from the west, with a general eastward slope towards the old agricultural lands. This site lies in the wadi deposits (sandy gravel) and the subsurface soils are highly porous and permeable [35]. There is a recharge site (Figure 2 ) that consists of eight infiltration basins.

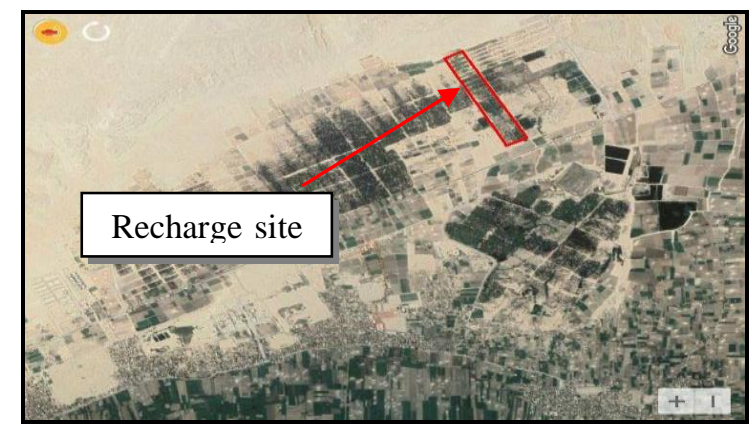

Fig. 2. Infiltration basin location.

Each one is alternately filled with partially treated wastewater (wetting/drying periods) from a single outlet at the edge of the basin as shown in Figure 3.

\subsection{Soil exploration}

Auger drilling is obtained to identify the arrangement of substrates. It is the most common method of soil exploration up to a depth of $60 \mathrm{~m}$ (Figure 4). The soil column was excavated, with an average of $50 \mathrm{~m}$ in-depth. The soil from the infiltration basin was sandy gravel from 0 up to 12 $\mathrm{m}$, fine-medium sand from 12 up to $20 \mathrm{~m}$, mediumcoarse sand with shale from 20 up to $36 \mathrm{~m}$, and medium-coarse sand with minor clay from 36 up to $50 \mathrm{~m}$ in depth.

\subsection{SAMPLES COLLECTION AND ANALYSIS TESTS}

Samples were collected from four different locations around the infiltration basin as shown in Figure 5, which are located at 500, 750, 1000, and $1500 \mathrm{~m}$. 
Vol.42, No.1. January2023

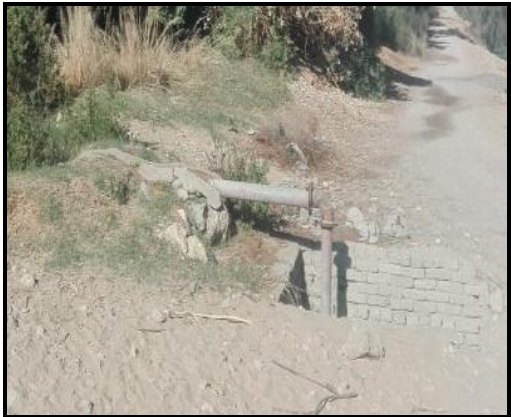

(a)

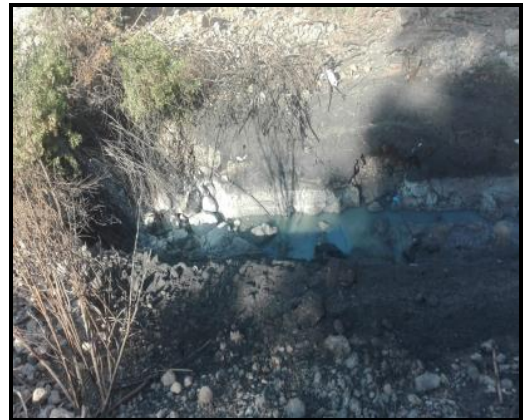

(b)

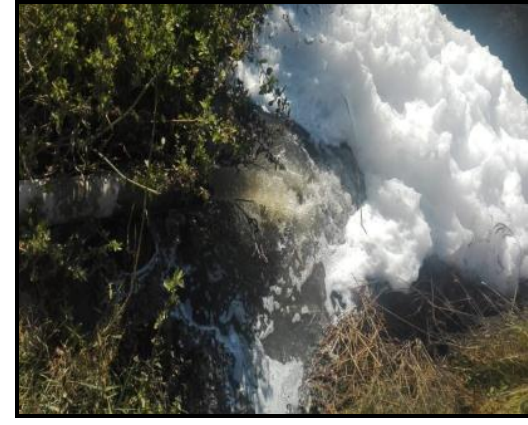

(c)

Fig. 3. Outlet of partially treated wastewater at the basin edge (source: site visit).

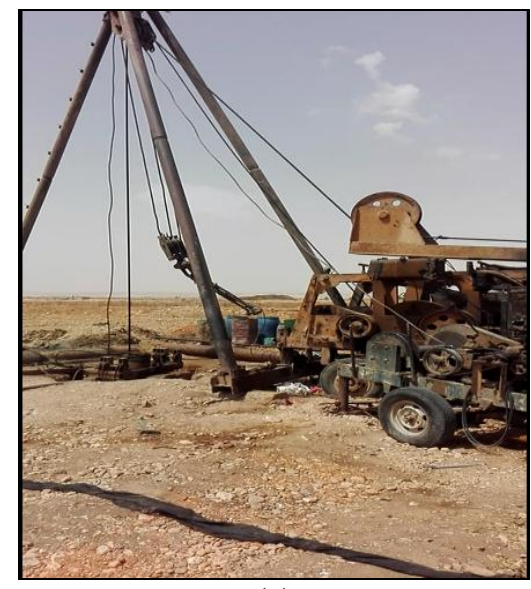

(a)

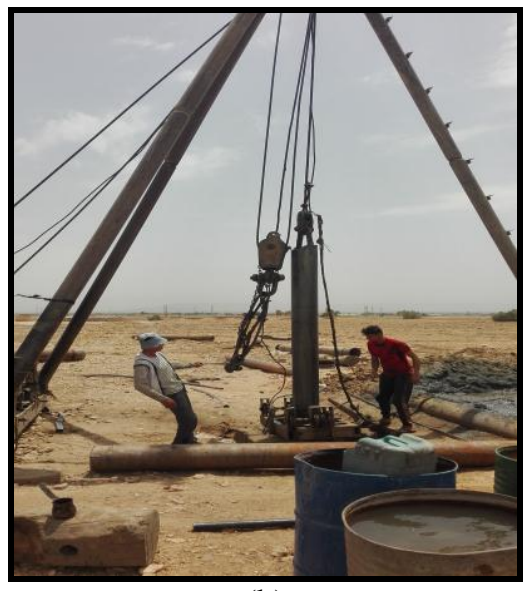

(b)

Fig. 4. Mechanical auger drilling.

The measurements were performed in the central laboratory of the Sohag water and wastewater company. Recharged and reclaimed water samples were collected in one-liter plastic bottles; their caps were closed right away to prevent air entry and were kept in a cooler with ice. The samples were transported from the field to the laboratory within one hour to be analyzed.

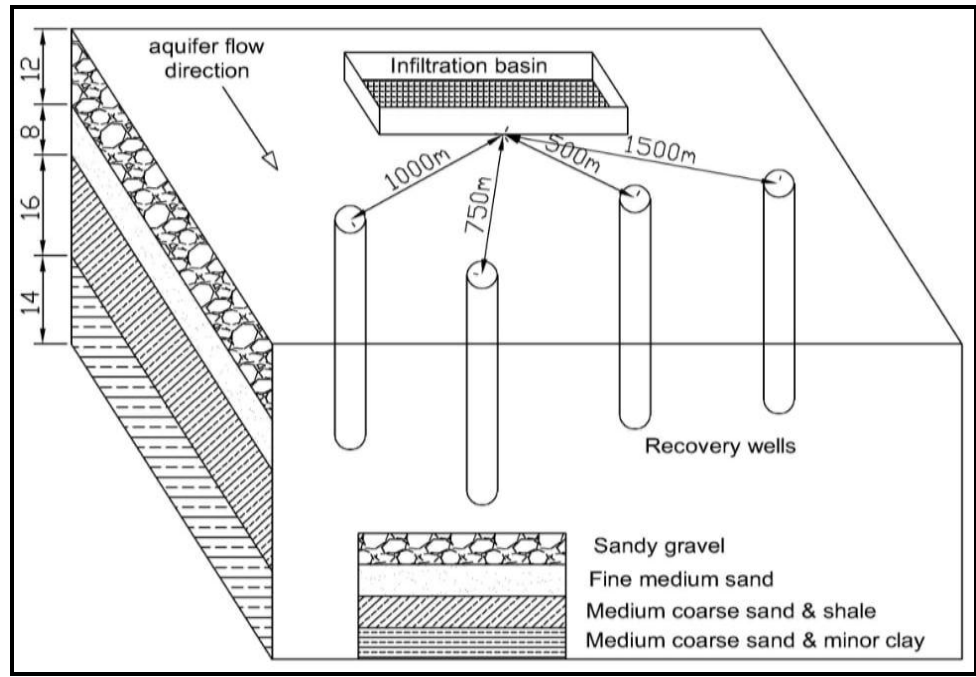

Fig. 5. Recovery wells location from the infiltration basin. Not to scale.

All laboratory measurements were performed according to the standard methods for the examination of water and wastewater $23^{\text {rd }}$ edition [36]. Organic nitrogen, total nitrogen, and ammonia concentration were determined in the laboratory using Kjeldahl method. Nitrite, nitrate, and phosphate were determined using DR/2000 Spectrophotometer. Heterotrophic bacteria were determined using Heterotrophic Plate Count method. The results of the groundwater samples 
after soil aquifer treatment were compared to the Egyptian Code of Practice [37], and Food and Agriculture Organization [38] limits for wastewater reuse.

To evaluate the SAT system in removing nutrients and improving wastewater quality, our measurements were concerned to organic nitrogen $(\mathrm{ON})$, ammonia $\left(\mathrm{NH}_{3}\right)$, nitrite $\left(\mathrm{NO}_{2}\right)$, nitrate $\left(\mathrm{NO}_{3}\right)$, phosphate $\left(\mathrm{PO}_{4}\right)$, total nitrogen $(\mathrm{TN})$, total Kjeldahl nitrogen (TKN), and heterotrophic bacteria (HB).

\section{RESULTS AND DISCUSSION}

The level of wastewater treatment achieved by the SAT system was indicated by comparing the recharged to the reclaimed water quality. The
The removal efficiency of nutrients and heterotrophic bacteria was calculated according to the following equation:

Removal $(\%)=(($ Inf Conc. - Eff Conc. $) /$ Inf Conc. $) \times 100$

Removal (\%) is the percentage of removal efficiency. Inf Conc. is the recharged water concentration. Eff Conc. is the reclaimed water concentration.

Table 1. Recharged and reclaimed water quality parameters.

\begin{tabular}{|c|c|c|c|c|c|c|c|c|}
\hline \multirow[t]{2}{*}{ Parameter } & \multirow[t]{2}{*}{ Unit } & \multirow{2}{*}{$\begin{array}{c}\text { Recharged } \\
\text { water }\end{array}$} & \multicolumn{4}{|c|}{$\begin{array}{c}\text { Samples at different distances from } \\
\text { the basin } \\
(\mathrm{m})\end{array}$} & \multirow{2}{*}{$\begin{array}{l}\text { FAO } \\
\text { limit }\end{array}$} & \multirow{2}{*}{$\begin{array}{l}\text { ECP } \\
\text { limit }\end{array}$} \\
\hline & & & 500 & 750 & 1000 & 1500 & & \\
\hline Organic nitrogen & $\mathrm{mg} / \mathrm{l}$ & 18.2 & 0.1 & 0 & 0 & 0 & - & - \\
\hline Ammonia & $\mathrm{mg} / \mathrm{l}$ & 46 & 0.2 & 0 & 0 & 0 & - & - \\
\hline Nitrite & $\mathrm{mg} / \mathrm{l}$ & 1.92 & 0 & 0 & 0 & 0 & - & - \\
\hline Nitrate & $\mathrm{mg} / \mathrm{l}$ & 16.4 & 41.25 & 41.75 & 40.62 & 41.82 & 5 & - \\
\hline Phosphate & $\mathrm{mg} / \mathrm{l}$ & 2.6 & 0 & 0 & 0 & 0 & 2 & 30 \\
\hline Total nitrogen & $\mathrm{mg} / \mathrm{l}$ & 82.52 & 41.55 & 41.75 & 40.62 & 41.82 & - & - \\
\hline $\begin{array}{l}\text { Total Kjeldahl } \\
\text { nitrogen }\end{array}$ & $\mathrm{mg} / \mathrm{l}$ & 64.2 & 0.3 & 0 & 0 & 0 & - & - \\
\hline $\begin{array}{c}\text { Heterotrophic } \\
\text { bacteria }\end{array}$ & $\mathrm{CFU} / \mathrm{ml}$ & 85000 & 134 & 69 & 30 & 2 & $<1000$ & 20 \\
\hline
\end{tabular}

\subsection{Organic nitrogen concentrations $(\mathrm{ON})$}

The comparison of ON concentrations between the recharged and the reclaimed water are shown in Table 1. It is observed that the recharged water has been naturally treated with excellent removal efficiency during SAT system. From Table 1, it is noticed that the $\mathrm{ON}$ concentration in the recharged water was $18.2 \mathrm{mg} / \mathrm{l}$. Then, it dropped sharply to $0.1 \mathrm{mg} / \mathrm{l}$ at a distance of about $500 \mathrm{~m}$. Nitrogen concentration can be decreased in the system via mobilization and movement to the aquifer, or it can be immobilized through both biotic and abiotic processes [39]. Biological immobilization occurs when the ions are either positive or negative charge. Immobilization increases the obstruction time for nitrogen reaching the aquifer. Furthermore, there are three main processes average recharged and reclaimed water quality parameters are presented in Table 1. 
Vol.42, No.1. January2023

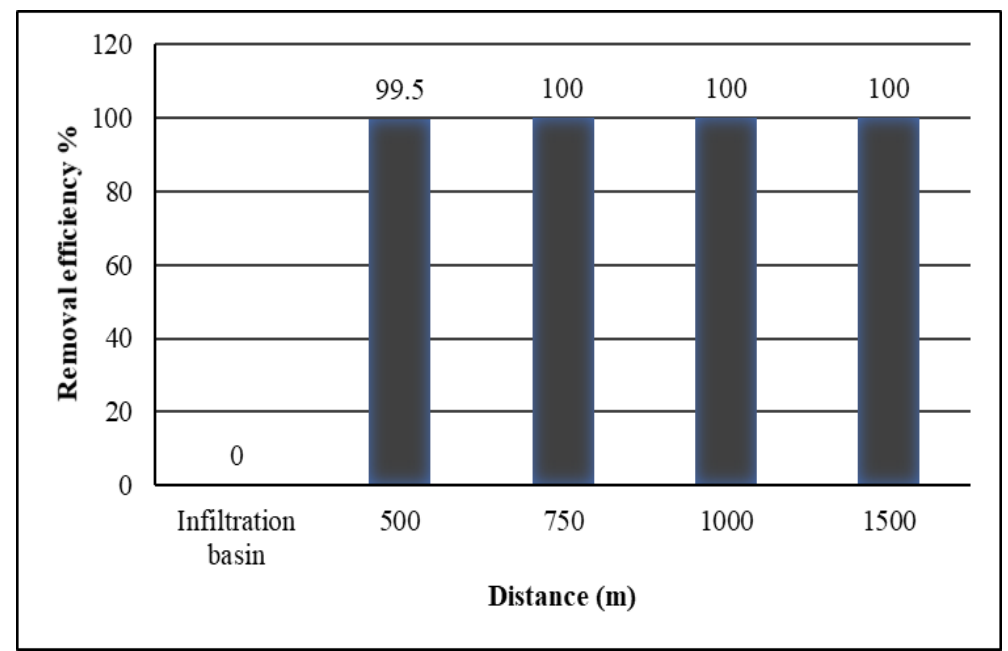

Fig. 6. Organic nitrogen (ON) removal efficiency at different distances from the infiltration basin.

\subsection{Ammonia concentrations $\left(\mathrm{NH}_{3}\right)$}

From Table 1, it is noticed that the $\mathrm{NH}_{3}$ concentration in the reclaimed water was lower than that of the recharged water. The concentration in the recharged water was $46 \mathrm{mg} / \mathrm{l}$. The concentration at $500 \mathrm{~m}$ was $0.2 \mathrm{mg} / \mathrm{l}$. This decrease in concentration is due to the following main process, removal of $\mathrm{NH}_{3}$ by nitrification occurring in the soil and the aquifer. Nitrification converts ammonia into nitrite as a first step and then converts nitrite to nitrate in the second step. Nitrification is an oxidation process; it is the most common way to biologically remove $\mathrm{NH}_{3}$ from wastewater. This process occurs in the presence of oxygen under aerobic conditions using bacteria (often Nitrosomonas) to oxidize $\mathrm{NH}_{3}$ to $\mathrm{NO}_{2}$.

Ammonia + Oxygen + Alkalinity + Nitrosomonas $=$ Nitrite (2)

Drying periods restore oxygen concentration in the vadose zone required for nitrification [40].
Moreover, $\mathrm{NH}_{3}$ is efficiently immobilized by clay minerals and organic matter $(\mathrm{OM})$ in sediment [41]. It is clearly noticed that, the $\mathrm{NH}_{3}$ concentration was completely removed (zero $\mathrm{mg} / \mathrm{l}$ ) with a removal efficiency of $100 \%$ at a distance of more than $500 \mathrm{~m}$ as shown in Figure 7. This finding agrees with [42], which reported that a higher removal efficiency of ammonia (95\%) was achieved using SAT system. This is maybe attributed to the natural dilution by the groundwater because of the horizontal movement through the aquifer. There are no guidelines by ECP and FAO for the maximum concentration of $\mathrm{NH}_{3}$ in the treated wastewater to be reused in agricultural purposes. Therefore, the reclaimed water is suitable for irrigating all crops.

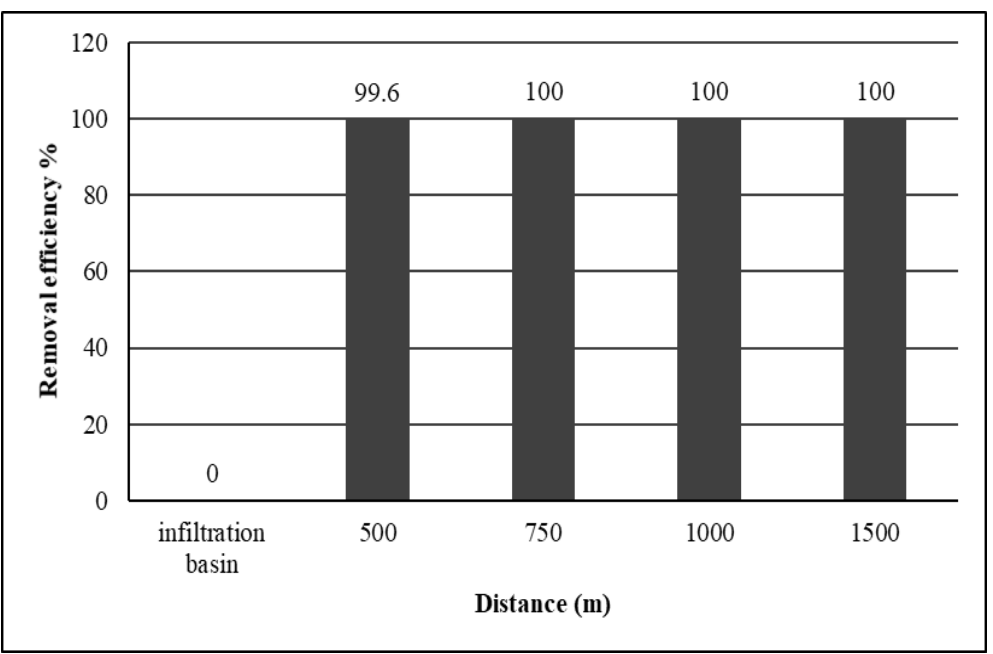

Fig. 7. Ammonia $\left(\mathrm{NH}_{3}\right)$ removal efficiency at different distances from the infiltration basin. 


\subsection{Nitrite concentrations $\left(\mathrm{NO}_{2}\right)$}

Table 1 shows the comparison of $\mathrm{NO}_{2}$ concentrations between recharged and reclaimed water samples. Results showed that, the recharged water has been naturally treated by SAT system. The concentration was $1.92 \mathrm{mg} / \mathrm{l}$ in the recharged water. $\mathrm{NO}_{2}$ concentration was completely removed through the vadose zone. In the second step of the nitrification process, oxidation occurs under aerobic conditions using a type of bacteria (often Nitrobacter) to oxidize the $\mathrm{NO}_{2}$ to $\mathrm{NO}_{3}$.

Nitrite + Oxygen + Alkalinity + Nitrobacter $=$ Nitrate

As oxygen in the vadose zone supports nitrification, SAT system can excel at nitrogen removal [43].

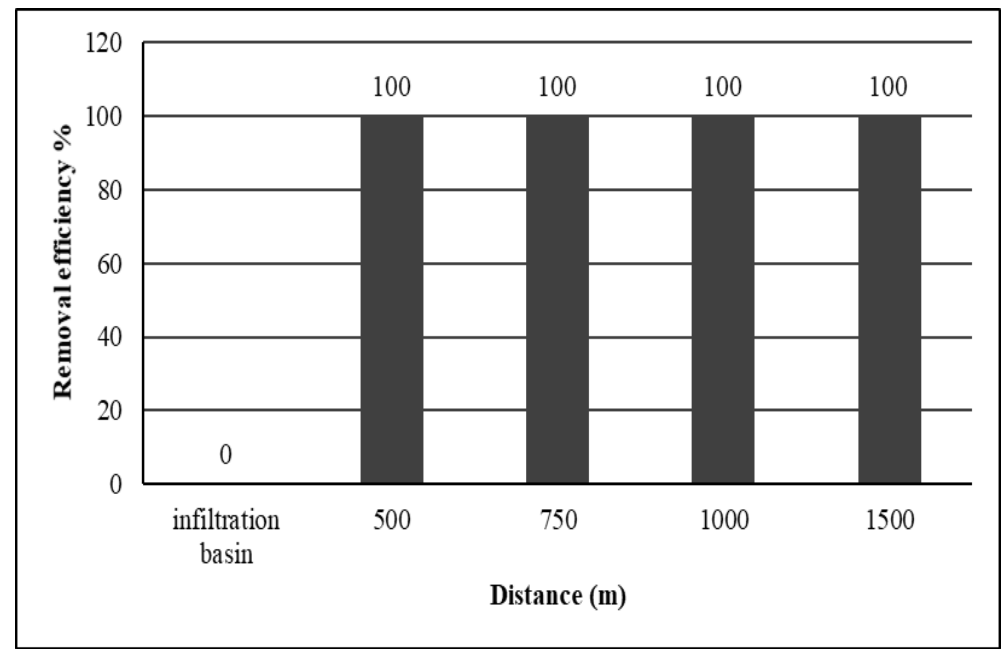

Fig. 8. Nitrite $\left(\mathrm{NO}_{2}\right)$ removal efficiency at different distances from the infiltration basin.

\subsection{Nitrate Concentrations $\left(\mathrm{NO}_{3}\right)$}

As water passes through the vadose zone, $\mathrm{NO}_{3}$ was the main existing form of total $\mathrm{N}$ in the infiltration basin. It was almost the only existing form after the recharged water reached the aquifer. The concentration of $\mathrm{NO}_{3}$ in the recharged water was $16.4 \mathrm{mg} / \mathrm{l}$. The concentration in the reclaimed water at distance of about $500 \mathrm{~m}$ was $41.25 \mathrm{mg} / \mathrm{l}$, at 750,1000 , and $1500 \mathrm{~m}$ was $41.75,40.62$, and 41.82 mg/l respectively. $\mathrm{NO}_{3}$ can move downwards and become a direct contaminant to groundwater, as it infiltrates through the vadose zone. $\mathrm{NO}_{3}$ naturally occur within the soil due to decomposition and organic matter. $\mathrm{NO}_{3}$ is removed by the common process denitrification (conversion of $\mathrm{NO}_{3}$ to nitrogen gas). Denitrification is a reduction process that occurs in the absence of oxygen under anoxic conditions using heterotrophic bacteria (usually pseudomonas) to reduce nitrate to nitric oxide, nitrous oxide and nitrogen gas.

Nitrate + organics + pseudomonas $=$ nitrogen gas +alkalinity (4)

$\mathrm{NO}_{3}$ concentrations showed irregular distribution concerning distance from the infiltration basin as shown in Table 1. Samples
Samples concentration at different distances 500, 750, 1000, and $1500 \mathrm{~m}$ were $0 \mathrm{mg} / \mathrm{l}$, with a removal efficiency of $100 \%$ as shown in Figure 8. This is due to the process by which $\mathrm{NO}_{2}$ is reduced to nitrous oxide $\left(\mathrm{N}_{2} \mathrm{O}\right)$ and nitrogen gas $\left(\mathrm{N}_{2}\right)$ by denitrifying bacteria under anaerobic conditions. According to ECP and FAO, there are no guidelines for the maximum concentration of $\mathrm{NO}_{2}$ in the treated wastewater. Thus, the reclaimed water is safe for agricultural reuse. 
Vol.42, No.1. January2023

reclaimed water is unsuitable for irrigation

purposes.

\subsection{Phosphate concentration $\left(\mathrm{PO}_{4}\right)$}

Table 1 illustrates the changes of $\mathrm{PO}_{4}$ concentrations in recharged and reclaimed water. As shown in Figure 9, $\mathrm{PO}_{4}$ concentration was completely removed from reclaimed water with a removal efficiency of $100 \%$. The results agree with [42], which reported that $\mathrm{PO}_{4}$ removal efficiency was $(\sim 90 \%)$ due to sorption. The removal of $\mathrm{PO}_{4}$ during the SAT system can be achieved by microbial uptake. The main processes responsible for $\mathrm{PO}_{4}$ removal are chemical precipitation and physical adsorption mechanisms. This is due to the large soil volume participating in the process, as well as the combined action of chemical and biological processes. The superior sorption performance may be explained by redox conditions within the storage zone. Furthermore, the depth of the vadose zone allows increasing the water residence time which leads to retaining $\mathrm{PO}_{4}$ in the porous medium. The particulate $\mathrm{PO}_{4}$ (mineral and/or organic) is physically retained by filtration on the surface of the filter bed. FAO, considered 2 $\mathrm{mg} / \mathrm{l}$ as a maximum contamination level (MCL) of $\mathrm{PO}_{4}$ in the treated wastewater that have to be used in agriculture. ECP, considered $30 \mathrm{mg} / \mathrm{l}$ is MCL for long and short-term use. All $\mathrm{PO}_{4}$ concentrations were below MCL. Therefore, we can consider that the reclaimed water is safe for agriculture purposes.

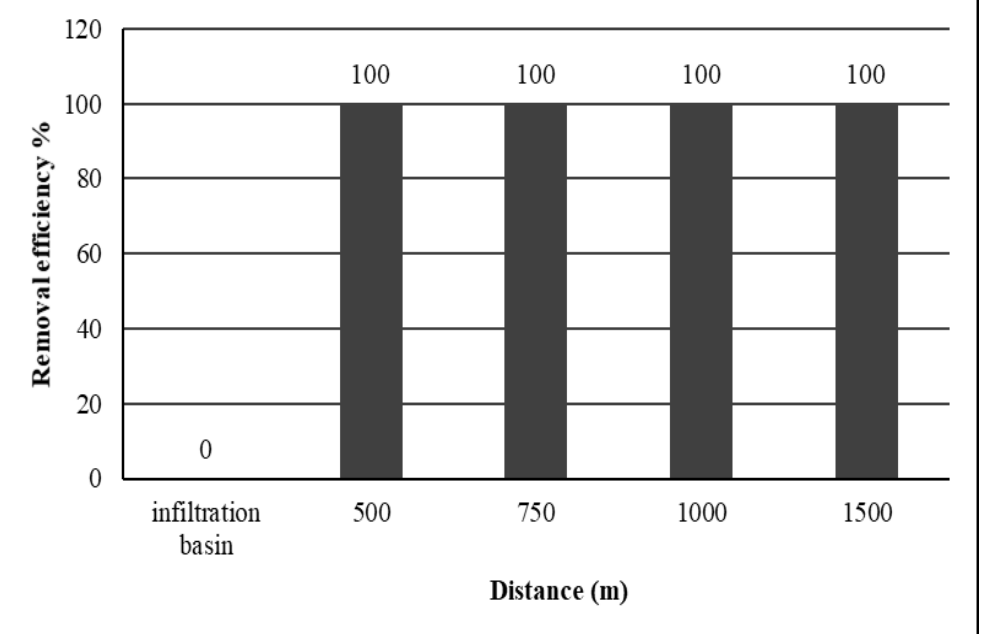

Fig. 9. Phosphate $\left(\mathrm{PO}_{4}\right)$ removal efficiency at different distances from the infiltration basin.

\subsection{Total nitrogen (TN)}

Total nitrogen was determined by calculation as the sum of the organic nitrogen, ammonia, nitrate, and nitrite. From Table 1, the concentration in the reclaimed water was reduced in comparison to the recharged water. The concentration in the reclaimed water was $82.52 \mathrm{mg} / \mathrm{l}$. It is decreased with the increase in distance from the infiltration basin. It was $41.55,41.75,40.62$, and $41.82 \mathrm{mg} / \mathrm{l}$ at 500, 750, 1000, and $1500 \mathrm{~m}$, respectively. Most of the nitrogen removal occurred in the vadose zone, and the nitrogen fraction that reached the aquifer (mostly $\mathrm{NO}_{3}$ ) continued to $1500 \mathrm{~m}$. TN removal was dominated by redox processes. As shown in Figure 10, TN decreased with an average removal efficiency of $50 \%$. The results agree with $[42,44]$, which reported that $\mathrm{TN}$ removal efficiency was 40 63\% during managed aquifer recharge (MAR) system. According to ECP and FAO, there are no guidelines for the maximum concentration of TN in the treated wastewater to be reused in agricultural purposes. So, the reclaimed water is suitable for irrigation. 


\section{Vol.42, No.1. January2023}

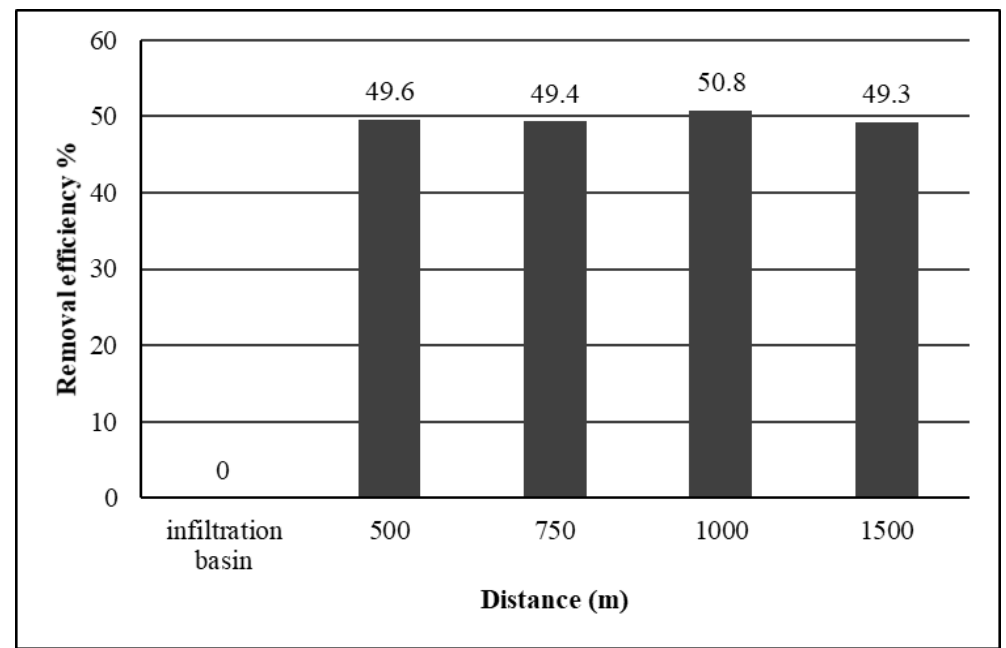

Fig. 10. Total nitrogen (TN) removal efficiency at different distances from the infiltration basin.

\subsection{Total Kjeldahl nitrogen (TKN)}

The total kjeldahl nitrogen represents the total of organic nitrogen and ammonia forms of nitrogen. As shown in Table 1, Kjeldahl nitrogen was removed very well by SAT system at a distance of more than $500 \mathrm{~m}$. The concentration in the recharged water was $64.2 \mathrm{mg} / \mathrm{l}$. After nearly 30 $\mathrm{m}$ percolation through the vadose zone, and $500 \mathrm{~m}$ lateral movement in the aquifer, TKN concentration reached to $0.3 \mathrm{mg} / \mathrm{l}$. Low TKN concentration with low $\mathrm{NH}_{3}$ nitrogen maybe caused by the ability of the microorganisms to break down compounds that are part of the ON. Furthermore, the removal of TKN was due to adsorption in the vadose zone. With the increase in lateral movement in the aquifer, TKN concentration decreased to zero $\mathrm{mg} / \mathrm{l}$. This is due to the natural dilution by the groundwater. From Figure 11, the overall TKN removal efficiency was $99.5 \%$ at $500 \mathrm{~m}$ and $100 \%$ at a distance of more than $500 \mathrm{~m}$.

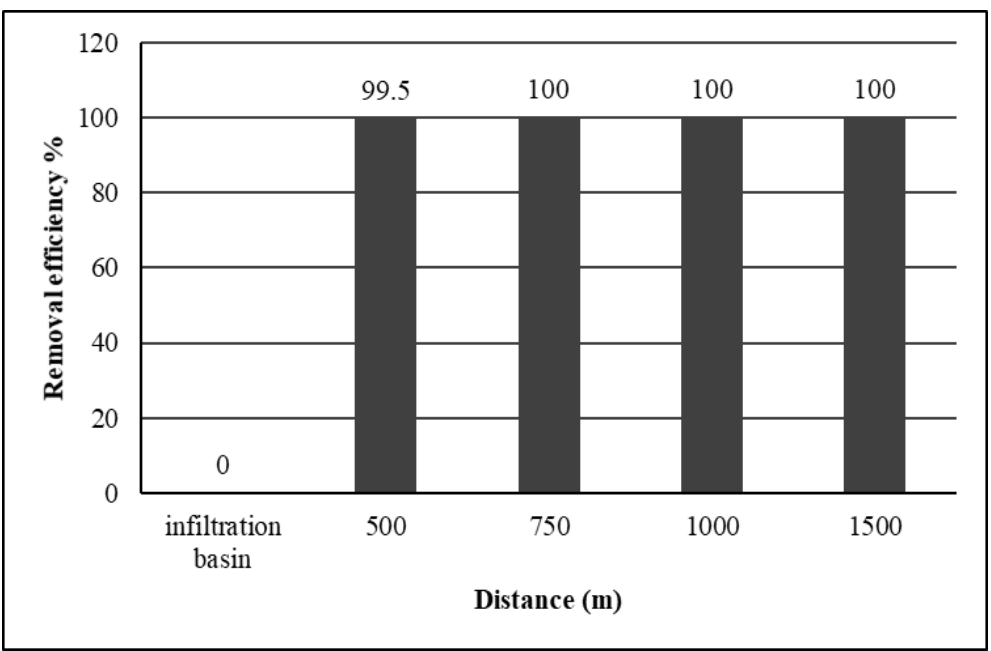

Fig. 11. Total kjeldahl nitrogen (TKN) removal efficiency at different distances from the infiltration basin.

\subsection{Heterotrophic bacteria $(\mathrm{HB})$}

Results indicated a significant influence of the vadose zone on bacterial concentration removal. From Table 1, it is observed that HB concentration decreased with the increase in depth to the aquifer (approximately $30 \mathrm{~m}$ ), and with the increase in distance from the infiltration basin. The concentration in the recharged water was 85000 $\mathrm{CFU} / \mathrm{ml}$. Due to the natural dilution with the aquifer, the concentration in the reclaimed water at different distances of 500, 750, 1000, and $1500 \mathrm{~m}$ was $134,69,30$, and $2 \mathrm{CFU} / \mathrm{ml}$, respectively. SAT system showed excellent removal of HB. As shown in Figure 12, the removal efficiency was about 99.9\% at all distances from the infiltration basin. This is in line with [45] findings. It is noticed that, bacterial transfers from the infiltration basin to 
groundwater was affected by the vadose zone and the aquifer. The soil greatly affects the number of microorganisms that remain in the recharged water greatly, as it passes through the layers before reaching the aquifer [46].

The decrease in the concentration is due to the major removal mechanisms occurring in the vadose zone that includes sand filtration, adsorption, and biological degradation. Depth of the vadose zone increases the sand particles' available surface area; this may significantly capture the bacteria from the recharged water. On the other hand, the removal rates improvement can be explained by the impact of travel time during percolation through the vadose zone. Moreover, attenuation of microorganisms during infiltration is achieved through inactivation, straining, and attachment to aquifer materials.

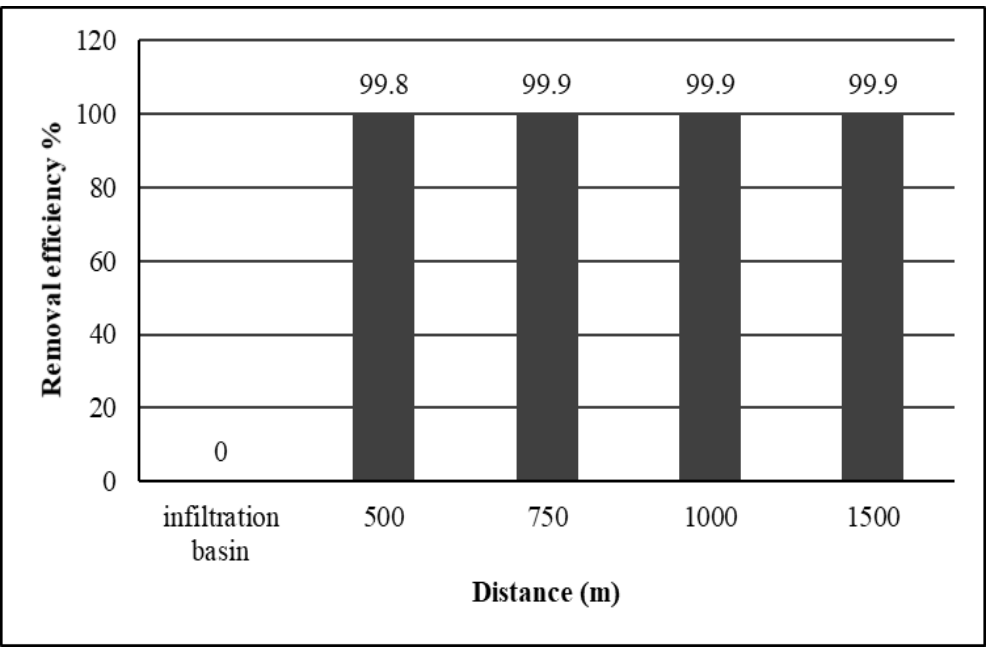

Fig. 12. Heterotrophic bacteria (HB) removal efficiency at different distances from the infiltration basin.

\section{CONCLUSIONS}

In this study, results indicated that the SAT system is very effective in removing nutrients from partially treated wastewater. The vadose zone plays an important role in wastewater treatment. It acts as a filter for the groundwater recharge, and it is more effective in removing contaminants that come from the land surface. Mixing of the recharged water with the groundwater and the slow movement through the aquifer increase the contact time with the aquifer and leading to further purification of water. The suitable distance for extracting the recharged water with acceptable quality is $750 \mathrm{~m}$. $\mathrm{ON}, \mathrm{NH}_{3}, \mathrm{NO}_{2}, \mathrm{PO}_{4}$, and TKN were effectively removed with an efficiency of $100 \%$. While TN concentration was removed with an efficiency of $50 \%$. SAT system is not effective in removing $\mathrm{NO}_{3}$ from the recharged water. $\mathrm{HB}$ concentration decreased with the increase in depth to the aquifer,

\section{REFERENCS}

[1]. Donn, M., Reed, D., Vanderzalm, J., \& Page, D. (2020). Assessment of E. coli attenuation during infiltration of treated wastewater: A pathway to future managed aquifer recharge. Water, 12(1), 173.

[2]. He, K., Asada, Y., Echigo, S., \& Itoh, S. (2020). Biodegradation of pharmaceuticals and personal care products in the sequential combination of activated sludge treatment and soil aquifer and with the increase in distance from the infiltration basin. The removal efficiency was $99.8 \%$ at $500 \mathrm{~m}$. According to the FAO and the $\mathrm{ECP}$, the reclaimed water is suitable for irrigation.

\section{RECOMMENDATIONS FOR FUTURE STUDIES}

- Study the performance of SAT system using different soil types by laboratory scale SAT system.

- Study using the recovered water in potable uses.

- Study the performance of SAT system for industrial water treatment and reuse this water for agricultural purposes. treatment. Environmental Technology, 41(3), 378-388.

[3]. Morrison, C. M., Betancourt, W. Q., Quintanar, D. R., Lopez, G. U., Pepper, I. L., \& Gerba, C. P. (2020). Potential indicators of virus transport and removal during soil aquifer treatment of treated wastewater effluent. Water Research, 177, [115812]. 
[4]. Bouwer, H. (2002). Artificial recharge of groundwater: Hydrogeology and engineering. Hydrogeology Journal, 10, 121-142.

[5]. Aharoni, A., \& Cikurel, H. (2006). Mekorot's research activity in technological improvements for the production of unrestricted irrigation quality effluents. Desalination, 187, 347-360.

[6]. Dillon, P. (2009). Water recycling via managed aquifer recharge in Australia. Boletin Geologico y Minero, 120(2), 121-130.

[7]. Drewes, J. E. (2009). Ground water replenisment with recycled water- water quality improvements during managed aquifer recharge. Ground Water, 47(4), 502-505.

[8]. Al-Maktoumi, A., Zekri, S., El-Rawy, M., Abdalla, O., Al-Abri, R., Triki, C. \& BazarganLari, M. R. (2020). Aquifer storage and recovery, and managed aquifer recharge of reclaimed water for management of coastal aquifers. Desalination and Water Treatment, 176, 67-77.

[9]. El-Rawy, M., Al-Maktoumi, A., Zekri, S., Abdalla, O. \& Al-Abri, R. (2019). Hydrological and economic feasibility of mitigating a stressed coastal aquifer using managed aquifer recharge: a case study of Jamma aquifer, Oman. Journal of Arid Land, 11(1), 148-159.

[10]. Kanarek, A., \& Michail, M. (1996). Groundwater recharge with municipal effluent: Dan Region reclamation project, Israel. Water Science and Technology, 34 (11), 227-233.

[11]. Goren, O., Burg, A., Gavrieli, I., Negev, I., Guttman. J., Kraitzer. T., Kloppmann, W., \& Lazar, B. (2014). Biogeochemical processes in infiltration basins and their impact on the recharging effluent, the soil aquifer treatment (SAT) system of the Shafdan plant, Israel. Applied Geochemistry, 48, 58-69.

[12]. Sharma, S. K., \& Amy, G. (2010). Natural treatment systems. In: water quality and treatment: A handbook on drinking water. (James K. Edzwald, ed.). Sixth Edition, American Water Works Association and McGraw Hill Inc., USA. Chapter 15, 15.115.33 .

[13]. Oudot, J., Ambles, A., Bourgeois, S., Gatellier, C., \& Sebyera, N. (1989). Hydrocarbon infiltration and biodegradation in a land-farming treatment, Environmental Pollution, 59, 17-40.

[14]. Van Cuyk, S., Siegrist, R., Logan, A., Masson, S., Fischer, E. \& Figueroa, L. (2001). Hydraulic and purification behaviors and their interactions during wastewater treatment in soil infiltration systems, Water Research, 35(4), 953-964.

[15]. Miller, J. H., Ela, W. P., Lansey, K. E., Chipello, P. L., \& Arnold, R. G. (2006). Nitrogen transformations during soil-aquifer treatment of wastewater effluent-oxygen effects in field studies. Journal of Environmental Engineering, 132(10), 12981306.

[16]. Sharma, S.K., \& Kennedy, M.D. (2017). Soil aquifer treatment for wastewater treatment and reuse. International Biodeterioration and Biodegradation, 119, 671-677.

[17]. Mienis, O., \& Arye, G. (2018). Long-term nitrogen behavior under treated wastewater infiltration basins in a soil-aquifer treatment (SAT) system. Water Research, 134, 192199.

[18]. Friedman, L., Mamane, H., Avisar, D., \& Chandran, K. (2018). The role of influent organic carbon-to-nitrogen $(\mathrm{COD} / \mathrm{N})$ ratio in removal rates and shaping microbial ecology in soil aquifer treatment (SAT). Water Research, 146, 197-205.

[19]. Siebe, C., Prado Pano, B. L., \& AlcantaraHernandez, R. J. (2019). Impacts of long-term wastewater irrigation on soil-aquifer interactions: evidences from the Critical Zone Observatory Valle del Mezquital, Central Mexico. American Geophysical Union, Fall Meeting 2019.

[20]. Shabani, F., Aflaki, R., Minamide, T., Venezia, T., \& Stenstrom, M. K. (2020). Soil aquifer treatment to meet reclaimed water requirements. Water environment research: a research publication of the Water Environment Federation, 92(2), 266-277.

[21]. Mills, W. R., Bradford, S. M., Rigby, M., \& Wehner, M. P. (1998). Groundwater recharge at the Orange County District. In: Asano, T. (ed.) Wastewater Reclamation and Reuse. Water Quality Management Library, (Vol. 10).

[22]. Bouwer, H. (2000). Integrated water management: emerging issues and challenges. Agricultural Water Management, 45(3), 217228.

[23]. Scanlon, B.R., Reedy, R.C., Faunt, C.C., Pool, D., \& Uhlman, K. (2016). Enhancing drought resilience with conjunctive use and managed aquifer recharge in California and Arizona. Environmental Research Letters, 11(3), 15.

[24]. Page, D., Bekele, E., Vanderzalm, J., \& Sidhu, J. (2018). Managed aquifer recharge (MAR) in sustainable urban water management. Water, 10(3), 239.

[25]. Ross, A. \& Hasnain, S. (2018). Factors affecting the cost of managed aquifer recharge (MAR) schemes. Sustainable Water Resources Management, 4, 179-190.

[26]. Baveye, P., Vandevivere, P., Hoyle, BL., DeLeo, PC., \& Sanchez de Lozada, D. (1998) Environmental impact and mechanisms of the biological clogging of saturated soils and aquifer materials. Critical Reviews in 
Environmental Science and Technology, 28(2):123-191.

[27]. Bouwer, H., Ludke, J., \& Rice, R.C. (2001). Sealing pond bottoms with muddy water. Ecological Engineering, 18(2), 233-238.

[28]. Humberto, H. A. M., Raoul, C. C., Lorenzo, V. V., \& Jorge, R.H. (2018). Aquifer recharge with treated municipal wastewater: long-term experience at San Luis Rio Colorado, Sonora. Sustainable Water Resources Management, 4,251-260.

[29]. Savvas, D., \& Adamidis, K. (1999). Automated management of nutrient solutions based on target electrical conductivity, $\mathrm{pH}$, and nutrient concentration ratios. Journal of Plant Nutrition, 22(9), 1415-1432.

[30]. Omer, A. A. M. (1996). Geological, mineralogical and geochemical studies on the Neogene and Quaternary Nile basin deposits, Qena-Assiut stretch, Egypt. Ph.D. Thesis, Geology Department, Faculty of Science, Sohag, South Valley University, Egypt.

[31]. Ali, M. H. (2005). Geochemical characteristics of the surfacial Nile basin sediments and their environmental relevance, Sohag area, Egypt. M.Sc. Thesis, Faculty of Science, South Valley University, Egypt.

[32]. Abdel Moneim, A. A. (1999). Geoelectric and hydrogeological investigation of the groundwater resources on the area to the west of the cultivated land at Sohag, Nile valley, Upper Egypt. Geological Society of Egypt, 43(2), 253- 268.

[33]. Abudeif, A. M. (2015). Integrated electrical tomography and hydro-chemical analysis for environmental assessment of El-Dair waste disposal site, west of Sohag city, Egyp. Environmental Earth Sciences, 74(7), 5859-5874.

[34]. CONOCO. (1987). Geological map of Egypt. Scale 1:250000. Egyptian General Petroleum Corporation and CONOCO Coral, Cairo.

[35]. El-Haddad, A., \& El-Shater, A. (1988). Sediments characteristics as a controlling factor of pollution of the groundwater from disposed of wastes, Sohag, Egypt. Sohag Pure \& Appl. Sci Bull Fac Sci, 4,145-162.

[36]. APHA, A. (2017). Standard methods for the examination of water and wastewater. Edition No: 23.

[37]. ECP-501. (2015). Egyptian code of practice for the use of treated municipal wastewater for agricultural purposes. The Ministry of Housing Utilities and Urban Communities, (In Arabic).

[38]. FAO. (1992). Wastewater Treatment and Reuse in Agriculture. M.B. Pescod. Irrigation and Drainage Paper No. 47. Rome, Italy.
[39]. Balesdent, J., \& Balabane, M. (1996). Major contribution of roots to soil carbon storage inferred from maize cultivated soils. Soil Biology and Biochemistry, 28(9), 1261-1263.

[40]. Trussell, S., Trussell, B., Qu, Y., \& Trussell, R. (2017). Soil Aquifer Treatment Charcterization with Soil Columns for Groundwater Recharge in the San Fernando Valley. Denver, Colorado: Water Research Foundation.

[41]. Liu, M., Hou, L., Xu, S., Ou, D., Yang, Y., Zhang, B., \& Liu, Q. (2002). Adsorption of phosphate on tidal flat surface sediments from the Yangtze Estuary. Environmental Geology, 42(6),657-665.

[42]. Vanderzalm, J., Page, D., Regel, R., Ingleton, G., Nwayo, C., \& Gonzalez, D. (2020). Nutrient transformation and removal from treated wastewater recycled via aquifer storage and recovery (ASR) in a Carbonate aquifer. Water Air Soil Pollution, 231, 65.

[43]. Essandoh, H., Tizaoui, C., Amy, G., \& Brdjanovic, D. (2011). Soil aquifer treatment of artificial wastewater under saturated conditions. Water Research, 45, 4211-4226.

[44]. Mienis, O., \& Arye, G. (2018). Long-term nitrogen behavior under treated wastewater infiltration basins in a soil aquifer treatment (SAT) system. Water Research, 134, 192-199.

[45]. Elkayam, R., Aharoni, A., Vaizel-Ohayon, D., Sued, O., Katz, Y., Negev, I., \& Lev, O. (2018). Viral and microbial pathogens, indicator microorganisms, microbial source tracking indicators, and antibiotic resistance genes in a confined managed effluent recharge system. Journal of Environmental Engineering, 144(3), 05017011.

[46]. Quanrud, D. M., Carroll, S. M., Gerba, C. P., \& Arnold, R. G. (2003). Virus removal during simulated soil-aquifer treatment. Water Research, 37, 753-762. 


\section{Vol.42, No.1. January2023}

إزالة المغذيات من مياه الصرف الصحي المعالجه جزئيا باستخدام تقنية المعالجه خلال طبقات التربه

الملخص العربي:

إن استخدام مياه الصرف الصحي المعالجة في الأنشطة الزراعية بطريقة مباشرة أو غير مباشرة في ازدياد لاسيما في المناطق التي تندر فيها المياه

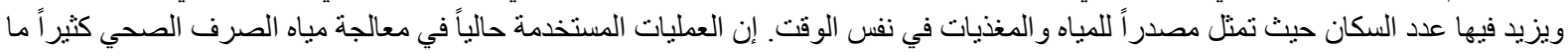

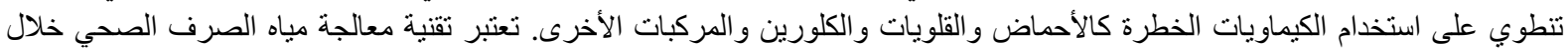

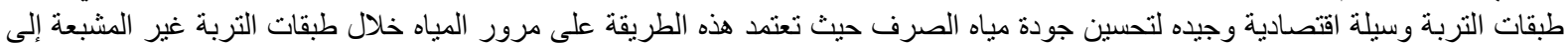

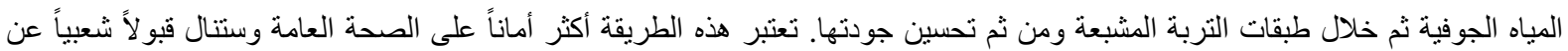

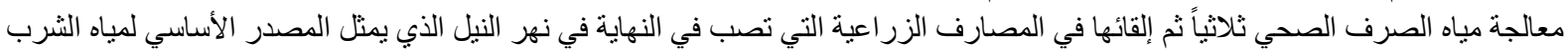

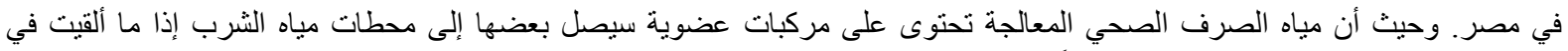

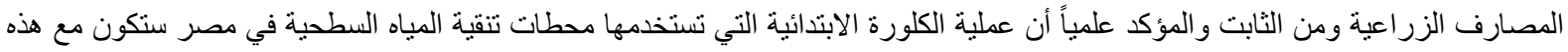

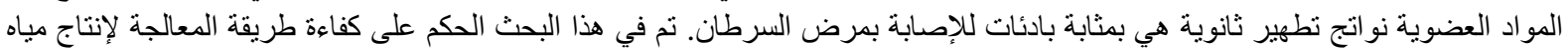

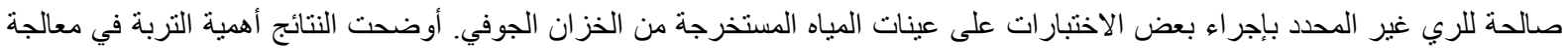

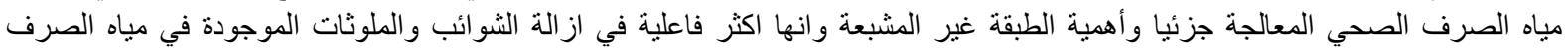
الصحي. كفاءة از الة البكتريا عضوية التغذية كانت

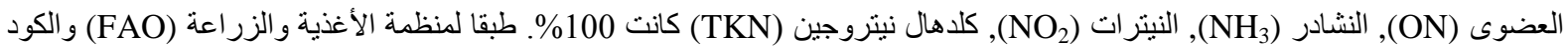
المصري (ECP-501,2015) المياه المستخرجة من ابار السحب مقبولة لري المزروعات. 